\title{
Vitrescent Dark Spot in Peach: a Preliminary Mineral Element
} Characterization

\author{
V. Fernandez, A. Blanco and J. Val ${ }^{\mathrm{a}}$ \\ Estación Experimental de Aula Dei (CSIC) \\ Avda. Montañana 1005 \\ 50059 Zaragoza \\ Spain
}

Keywords: Prunus persica, fruit quality, fruit storage, physiopathologies, calcium, mineral elements

\begin{abstract}
The occurrence of physiological disorders in fruits lead to major economic losses associated with decreased quality and post-harvest storability of commodities. Peach fruits affected by vitrescent dark spot lose their intrinsic high value and may not even reach the market. The existing lack of information on the peach "vitrescent dark spot" has led to preliminary trials to learn about the nature of such disorders in terms of nutrient balances and structural modifications. Analysis of mineral elements in the injured tissues has shown that $\mathrm{Ca}$, and $\mathrm{Mg}$ concentrations were greater than in the mesocarp of sound fruits, while in sound mesocarp of affected fruits, the concentrations were smaller. For $K$, the opposite situation was found. Besides, analysis of mesocarp of affected fruits showed increasing concentrations of $\mathrm{Ca}$ and $\mathrm{Mg}$ from sound tissue towards the spot, being greatest close to the spot. Changes in concentration have been found for other mineral nutrients, such as $\mathrm{N}, \mathrm{B}$, etc., while other elements such as $C$ and $S$ did not vary in concentration. The results show a similar behaviour in mineral element distribution to that of bitter pit in apple, thus suggesting that the vitrescent dark spot in peach is a calcium related physiopathology.
\end{abstract}

\section{INTRODUCTION}

Late ripening cultivars in Spain, particularly those grown in the Calanda area (Teruel, Spain), attain very high prices because the fruits are bagged shortly after fruit thinning has been accomplished. Consequently, when collected at harvest no residues of pesticides are found on them, and so, these fruits are marketed as pesticide free. The marketing season of this commodity is now being extended as much as possible, by storing the fruits under cold conditions.

However, new physiological disorders are being reported by growers, of which the "vitrescent dark spot" (VDS) is becoming the cause for important economic loses. At harvest, there is great difficulties in discerning affected fruits from sound fruits, of good marketing quality, as is the case for bitter pit in apple, although the spot is already developed (Val, 2007).

In this paper, preliminary work carried out to study the mineral element characterization of this newly observed disorder is presented.

\section{MATERIALS AND METHODS}

In 2007, peaches from one orchard in Caspe (Zaragoza, Spain) of "Calrico", a Calanda late season cultivar, were collected and brought to the laboratory. Fruits were separated according to the degree of ripening, based on fruit skin colour, and fruits from both classes were randomly separated into three groups.

In each group of fruits, four tissues were surgically excised (Fig. 1): mesocarp from sound peaches, spots, and in VDS-affected fruits sound mesocarp located close to the spot (here onwards called adjacent) or sound mesocarp away from the spot. They were

\footnotetext{
ajval@eead.csic.es
} 
homogenized and freeze-dried for mineral analysis. Materials from each group were separately processed. The analysis was made at the Servicio de Ionómica of CEBAS (CSIC) by ICP-OES for $\mathrm{Ca}, \mathrm{Mg}, \mathrm{K}$ and $\mathrm{B}$, and $\mathrm{N}$ and $\mathrm{C}$ were analyzed by elemental analysis following the Duma's method.

\section{RESULTS AND DISCUSSION}

Grower's reports on the development of a new physiopathology in peach have led to the accomplishment of studies to describe this disorder, previous to the development of management techniques that could lead towards the control of the disorder.

The detailed examination of fruits has shown that VDS in peach can develop before fruit maturation starts (Fig. 2). This led to a sorting of the fruits into 2 classes, based on the ripening state of the fruits, and the observation of fruits showed that, in the pre-ripening state, the spots are small, as if they were in an early stage of development. Subsequently, mineral analysis of tissues was made separately in the spots at early stages of development in unripe fruits, or in fully developed spots on mature fruits.

The results of the analysis of $\mathrm{Ca}$ and $\mathrm{Mg}$ concentrations show that the VDS in peach is similar to bitter pit of apples, as described by Aznar et al. (2001a, b) and Val et al. (2008) in terms of mineral element changes in concentrations (Table 1). In the spot, the concentration of these two elements is far greater than in sound tissue of the affected peach. In sound mesocarp of VDS affected fruits the concentration of these elements is lower than in the mesocarp of sound fruits, suggesting a movement of these elements towards the damaged tissues. For $\mathrm{K}$, the concentration in the spot is lower than in sound fruits, and an accumulation in the adjacent tissue happens to occur (Table 1). For $\mathrm{N}$ and $\mathrm{B}$ an accumulation of these elements have been found in affected fruits, as both the spot and the rest of the mesocarp have greater concentrations of these elements, although the maximum is found in tissue adjacent to the spot. Finally $\mathrm{C}$ distribution in the mesocarp is not affected by the development of the VDS.

When analyzing the development of the spots according to the stage of fruit ripening (Table 2), the results show that $\mathrm{Ca}, \mathrm{Mg}, \mathrm{N}$ and $\mathrm{B}$ concentrations in the spot increase since the initial stage of development, when fruits are unripe, attain their greatest concentration when the fruit is ripened and the VDS fully developed. On the contrary, for $\mathrm{K}$ an increase in concentration occurs in the earlier stages of VDS development, to decrease later when it is fully developed, while $\mathrm{C}$ is unaffected at any stage of development.

\section{CONCLUSIONS}

Data here presented show a pattern of behaviour of mineral elements of the vitrescent dark spot of peaches similar to that of bitter pit of apples. Consequently, these preliminary results suggest that this physiological disorder of peaches is related to calcium metabolism in fruits, for which, it is suggested the application of calcium treatments to control its development. Further work is in progress to confirm this hypothesis.

\section{ACKNOWLEDGEMENTS}

Work financed by DGA (PM005/2006) and INIA (PET2007-09-COS-02, Plan de Actuación Específico para Teruel). The authors acknowledge Mr. J.L. Espada (CTA DGA) for collecting the fruits for the analysis.

\section{Literature Cited}

Aznar, Y., Cortés, E., Blanco, A. and Val, J. 2001a. Gradientes nutricionales en manzanas afectadas por bitter pit. Actas de Horticultura 31:1679-1693.

Aznar, Y., Cortés, E., Monge, E., Blanco, A. and Val, J. 2001b. Caracterización catiónica $\mathrm{y}$ aniónica de las manchas de bitter pit en manzanas de tipo Golden. Actas de Horticultura 29:462-470.

Val, J. 2007. Calidad del melocotón de Aragón. Estudio de calciopatías (mancha 
vitrescente) por métodos convencionales, espectroscópicos y diagnóstico precoz. Nutri-fitos 171:87-98.

Val, J., Gracia, M.A., Monge, E. and Blanco, A. 2008. Visual detection of calcium by GBHA staining in bitter pit affected apples. Food Science and Technology Intl. 14:315-319.

\section{Tables}

Table 1. Mineral element concentrations of the "vitrescent dark spot", and of sound tissue of affected fruits collected either away or adjacent to the spot compared to the concentrations of these elements in the mesocarp of sound fruit (Percentage of value in sound fruit).

\begin{tabular}{lrrrrrr}
\hline Tissue & $\mathrm{Ca}$ & $\mathrm{Mg}$ & $\mathrm{K}$ & $\mathrm{N}$ & $\mathrm{C}$ & $\mathrm{B}$ \\
\hline Sound fruit & 100 & 100 & 100 & 100 & 100 & 100 \\
VDS-affected fruits & & & & & & \\
Tissue away from the spot & 61.6 & 94.9 & 91.4 & 138.9 & 100.9 & 120.1 \\
Tissue adjacent to the spot & 195.3 & 119.2 & 123.0 & 220.0 & 99.8 & 166.6 \\
V.D. Spot & 135.8 & 105.1 & 86.6 & 172.2 & 101.7 & 121.9 \\
\hline
\end{tabular}

Table 2. Changes in the concentration of mineral elements according to the stage of ripening of the fruit (Percentage of value in sound fruit).

\begin{tabular}{lrrrrrr}
\hline Tissue & $\mathrm{Ca}$ & $\mathrm{Mg}$ & \multicolumn{1}{c}{$\mathrm{K}$} & $\mathrm{N}$ & $\mathrm{C}$ & $\mathrm{B}$ \\
\hline Sound fruit & 100 & 100 & 100 & 100 & 100 & 100 \\
Spot at Initial stage & 124.4 & 99.8 & 114.6 & 131.1 & 99.1 & 116.1 \\
Spot fully developed & 135.8 & 105.1 & 86.6 & 172.2 & 101.7 & 121.9 \\
\hline
\end{tabular}




\section{Figures}

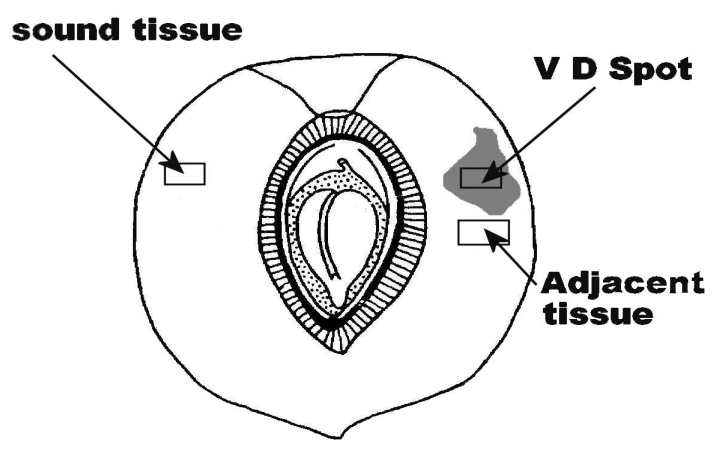

Fig. 1. Diagram of a peach showing the locations of tissue collection for analysis.
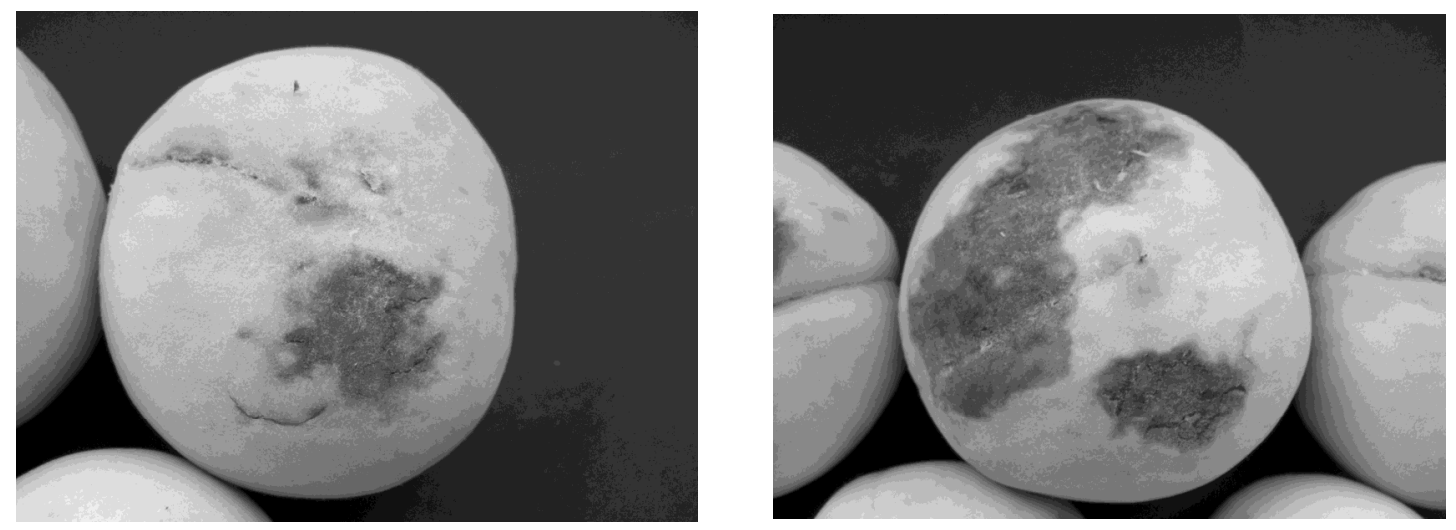

Fig. 2. "Vitrescent dark spot" in unripe (left) or ripe peaches (right). 